\title{
Cloning, Characterization, and Expression of a G-Protein-Coupled Receptor from Lymnaea stagnalis and Identification of a Leucokinin-Like Peptide, PSFHSWSamide, as Its Endogenous Ligand
}

\author{
Kingsley J. A. Cox, ${ }^{1}$ Cornelis P. Tensen, ${ }^{2}$ Roel C. Van der Schors, ${ }^{4}$ Ka Wan Li, ${ }^{4}$ Harm van Heerikhuizen, ${ }^{3}$ \\ Erno Vreugdenhil, ${ }^{3}$ Wijnand P. M. Geraerts, ${ }^{4}$ and Julian F. Burke ${ }^{1}$ \\ 1Sussex Centre for Neuroscience, School of Biological Sciences, University of Sussex, Brighton BN1 9QG, United \\ Kingdom, ${ }^{2}$ Amsterdam Leiden Institute for Immunology, Vrije Universiteit Hospital, 1081 HV Amsterdam, The \\ Netherlands, and Departments of ${ }^{3}$ Biochemistry and ${ }^{4}$ Molecular Neurobiology, Graduate School of Neurosciences \\ Amsterdam, Institute of Neuroscience, Vrije Universiteit, 1081 HV Amsterdam, The Netherlands
}

\begin{abstract}
Neuropeptides are known to be important signaling molecules in several neural systems of the pond snail Lymnaea stagnalis. Although the functions of these peptides have been studied in many neurons, the nature of the postsynaptic signal transduction is mainly unknown. The cloning and characterization of neuropeptide receptors in Lymnaea thus would be very valuable in further elucidating peptidergic pathways. Indirect evidence suggests that these neuropeptides operate via G-protein-coupled mechanisms indicating the presence of
\end{abstract}

G-protein-coupled receptors as the initial postsynaptic targets. Here we describe the cloning of a neuropeptide receptor from Lymnaea and the isolation of an endogenous ligand. This peptide, PSFHSWSamide, belongs to the leucokinin family of peptides, and, thus, this Lymnaea receptor is the first example of a leucokinin-like neuropeptide receptor, representing a new subfamily of G-protein-coupled neuropeptide receptors.

Key words: neuropeptide receptor; mollusc; CHO-K1; HPLC; calcium; neural networks
Leucokinins comprise a family of peptides that are found in the CNS of insects and have been shown to be involved in diuresis (Hayes et al., 1989; Coast et al., 1990). For instance, leucokinin VIII significantly increases the rates of transepithelial $\mathrm{NaCl}, \mathrm{KCl}$, and water secretion in Malpighian tubules of the yellow fever mosquito Aedes aegypti (Pannabecker et al., 1993). The leucokinins were first isolated from the cockroach through their ability to induce cockroach hindgut contraction (Holman et al., 1986a,b, 1987a,b); subsequently, leucokinin-related peptides were found in the cricket (Holman et al., 1990) and the locust (Schoofs et al., 1992), all through the use of the hindgut bioassay. To date, 23 members of this family have been isolated: eight from the cockroach, five from the cricket Acheta domesticus, one from the locust Locusta migratoria, three from the mosquito Culex Salinarius (Clottens et al., 1993), three from the mosquito Aedes aegpti (Veenstra, 1994), and three from the earworm Helicoverpa zea (Blackburn et al., 1996). Immunocytochemistry has been used to determine the anatomical location of leucokinins and leucokininrelated peptides in insects, showing then to be in many areas of the CNS (Lundquist et al., 1993; Nassel, 1993; Chen et al., 1994). They have not yet been isolated from any other species, although immunocytochemical studies using antisera raised to insect leucokinins have indicated the presence of leucokinin-like peptides

\footnotetext{
Received July 9, 1996; revised Nov. 7, 1996; accepted Nov. 22, 1996.

This work was supported by a Jersey (Channel Islands, UK) studentship to K.C. and a European Community biotechnology contract. We thank Dr. L. Mayne at the Trafford Centre for Medical Research (Sussex, UK). We also thank Dr. Chris Hughes, Micromass UK Limited, for performing the tandem mass spectrometry. Correspondence should be addressed to Dr. Julian F. Burke, Molecular Neuroscience Group, Biochemistry Laboratory, University of Sussex, Brighton BN1 9QG, UK.

Dr. Cox's present address: Department of Neurobiology and Behavior, State University of New York at Stony Brook, Stony Brook, NY 11794-5230.

Copyright (C) 1997 Society for Neuroscience 0270-6474/97/171197-09\$05.00/0
}

in the CNS of the parasitic nematode Ascaris suum (Smart et al., 1993), the spider Cupiennius salei (Schmid and Becherer, 1996), and also in the mollusc Helix pomata (Elekes et al., 1994).

It is likely that the leucokinins and leucokinin-related peptides constitute an important group of peptides in insects and invertebrates in general, considering their myotropic actions and involvement in the control of water and electrolyte levels. Further studies on their function are hampered by a paucity of data regarding the postsynaptic sites of action; hence, the identification and characterization of a leucokinin receptor would be of great value with respect to this. The CNS of the pond snail Lymnaea stagnalis is one of the best understood systems in terms of defined neural networks and their relation to behavior, especially with respect to neuropeptides (Benjamin and Burke, 1994); thus, we have attempted to use this animal to characterize neuropeptide receptors. Molecular cloning techniques were used to isolate cDNAs encoding neuropeptide receptors from the CNS of Lymnaea. One of these cDNAs, designated GRL104, encoded a protein that had features previously described for other neuropeptide receptors. GRL104 was expressed in stably transfected CHO-K1 cells, and the peptide ligand was identified by the novel use of a multistep HPLC approach, together with a functional calcium assay. The peptide sequence was deduced to be PSFHSWSamide. When this peptide was analyzed for sequence homology against a protein database, it showed very high homology to the leucokinin family of peptides, especially leucokinins IV and VI, with five of the last six C-terminal residues being identical to the purified Lymnaea peptide. This is the first report of a leucokinin-related peptide being isolated from the CNS of an animal other than insects.

Some of this work has been presented previously in abstract form (Tensen et al., 1994a). 


\section{MATERIALS AND METHODS}

Animals. Adult Lymnaea stagnalis (shell height $28-34 \mathrm{~mm}$ ) were bred in the laboratory under standard conditions.

Molecular procedures. Standard procedures were performed as described by Sambrook et al. (1989). Restriction enzymes were purchased from NBL (UK) or Boehringer Mannheim (Indianapolis, IN). Synthetic oligonucleotides were synthesized on an ABI 380A synthesizer.

Polymerase Chain Reaction (PCR). PCR reactions were performed in $100 \mu \mathrm{l}$ volumes containing $50 \mathrm{~mm} \mathrm{KCl,} 10 \mathrm{~mm}$ Tris- $\mathrm{HCl}, \mathrm{pH} 8.3,1.5 \mathrm{~mm}$ $\mathrm{MgCl}_{2}, 0.01 \%$ gelatin, $200 \mu \mathrm{M}$ each dNTP, and 5-100 pmol of primers in a Perkin-Elmer (Norwalk, CT) 9600 thermal cycler, using 1 U AmpliTaq (Perkin-Elmer) or $0.2 \mathrm{U}$ of SuperTaq (HT Biotechnologies, Cambridge, UK)

$c D N A$ library screening. Total RNA isolated from Lymnaea CNS was converted into first strand cDNA using oligo(dT) Dynabeads (Dynal, Oslo, Norway) and reverse transcription. Two primers were synthesized corresponding to DNA sequences within conserved regions of transmembrane (TM) III and TM VI of many G-protein-coupled receptors (Libert et al., 1989) [sense (S1) 5'-CCGGATCCG(CT)(GC)AT(CT)(GA)(GC)(GC)IT(GT)GAC(CA)G(GC)TA-3'; antisense (A1) 5'-ACGAATTCGG(GC)(CA)ICCA(GA)CAGAI(GC)(GA)(CT)(GA)AA-3']. These were used in a $\mathrm{PCR}$ reaction under the following conditions: denaturation at $96^{\circ} \mathrm{C}$ for $10 \mathrm{~min}$ and then 48 cycles at $94^{\circ} \mathrm{C}$ for $40 \mathrm{sec}, 50^{\circ} \mathrm{C}$ for $2 \mathrm{~min}$, and $72^{\circ} \mathrm{C}$ for $3 \mathrm{~min}$. Multiple PCR products were generated, and those of the expected size $(400-800 \mathrm{bp})$ were recovered from an agarose gel with a pipette tip and reamplified in 32 cycles under identical conditions. The total PCR mix was cloned in pBluescript II KS+ (Stratagene, La Jolla CA) for sequence analysis. Oligonucleotides based on these sequences were used as primers in a PCR-based screening (Bloem and Yu, 1990) of a $\lambda$ ZAP II Lymnaea CNS cDNA library, modified as described previously (Tensen et al., 1994b). Approximately $10^{6}$ independent clones, amplified in 10 aliquots of $10^{5}$ original clones each, were constructed from poly $\left(\mathrm{A}^{+}\right)$ mRNA from Lymnaea CNS using a commercial cDNA synthesis [with oligo (dT) priming] and cloning system according to the manufacturer's instructions. To isolate the corresponding full-length cDNA clones, we excised cDNA inserts from these clones in vivo as phagemids and sequenced them. DNA sequences were determined from both strands, using the dideoxy chain termination method (Sanger et al., 1977) with denatured double-stranded DNA as a template and using the Sequenase DNA sequencing kit (United States Biochemicals, Cleveland, OH). Automated sequencing was also performed with an ABI 373 automated DNA sequencer. One clone, GRL104, showed high identical amino acid homology $(30 \%)$ to the neuropeptide Y receptor when the GenBank database was screened.

Transfection of GRL104 into CHO-K1 cells. A Kozak optimal ribosomal binding consensus sequence ( $5^{\prime}$ TTTGGATCCGCCATGGCTCAAATCGAGTCGATGTCCG 3'; the start ATG is highlighted in bold) was incorporated, using PCR, around the presumed start ATG (Kozak, 1986) of the Lymnaea receptor sequence. Then this modified sequence was cloned into the Bam $\mathrm{HI} / X b a \mathrm{I}$ sites of the mammalian expression vector pcDNA1/neo (Invitrogen, San Diego, CA), which contains a cytomegalovirus promoter, an SV40 origin of replication, and the neomycin resistance gene. The resulting expression construct, pcD104, was transfected into CHO-K1 cells by lipofection with Lipofectin Reagent (Life Technologies, Gaithersburg, MD) according to the manufacturer's instructions, and stably expressing $\mathrm{CHO}-\mathrm{K} 1$ clones were generated by continuous selection with $400 \mu \mathrm{g} / \mathrm{ml}$ of the neomycin analog G-418 in DMEM supplemented with $10 \%$ fetal calf serum and $1 \%$ glutamine.

Assay for the ligand to GRL104. CHO-K1 cells stably transfected with pcD104 were resuspended in PBS containing $1 \mathrm{mM} \mathrm{CaCl}$ at a concentration of $2 \times 10^{6}$ cells $/ \mathrm{ml}$. Fura-2-acetoxymethyl ester (Molecular Probes, Eugene, OR) was added to the cells at a final concentration of 1 $\mu \mathrm{M}$. The cells were kept at $4^{\circ} \mathrm{C}$ for $60 \mathrm{~min}$ to allow the Fura- 2 ester to penetrate. The cells were washed with PBS three times and then resuspended in PBS containing $1 \mathrm{mM} \mathrm{CaCl}_{2}$ and $0.1 \% \mathrm{BSA}$ at a concentration of $2 \times 10^{6}$ cells $/ \mathrm{ml}$. The cells were kept on ice until the fluorescence assay (a time gap of no more than $10 \mathrm{~min}$ ). One milliliter of cell suspension was warmed rapidly to $37^{\circ} \mathrm{C}$ in a quartz cuvette, which was placed in a heated cuvette chamber containing an integral magnetic stirrer. The cells were stirred constantly during the experiments. The fluorescence spectrophotometer (Beckman, Fullerton, CA) was set to excite at $340 \mathrm{~nm}$ and monitor emission at $510 \mathrm{~nm}$, and fluorescence changes were recorded on a chart recorder running at $10 \mathrm{~cm} / \mathrm{min}$. The slit width was $10 \mathrm{~nm}$, and the response time was two seconds. Dissolved ligands or HPLC fractions were added to the cell suspension; fluorescence responses, if they oc- curred, were measured immediately. To establish the maximum and minimum amounts of fluorescence in each assay, we added Triton X-100 to achieve a final concentration of $0.1 \%$ and then EGTA to achieve a final concentration of $10 \mathrm{mM}$. Intracellular calcium concentrations were quantitated with equations described by Grynkiewicz et al. (1985).

Extraction and purification of lymnokinin. Five hundred CNS were dissected, collected on dry ice, and stored at $-60^{\circ} \mathrm{C}$ until use. They were homogenized in an all-glass Elvehem-Potter homogenizer in $5 \mathrm{ml}$ of 0.1 $\mathrm{M}$ acetic acid over ice, boiled for $5 \mathrm{~min}$, and centrifuged at $4^{\circ} \mathrm{C}$ for $5 \mathrm{~min}$. The supernatant was filtered and applied to a C18 solid-phase extraction column (Supelclean, Supelco, Bellefonte, PA), and bound material was eluted with a mixture of $60 \%$ acetonitrile and $7.0 \mathrm{~mm}$ trifluoroacetic acid (TFA). The crude peptide fraction was subjected immediately to highperformance gel permeation chromatography (HPGPC), which consisted of applying the crude peptide extract to Protein-Pak columns I-125 and I-300 connected in series (Water Associates, Milford, MA), using a running solvent of $7 \mathrm{~mm}$ TFA in $30 \% \mathrm{CH}_{3} \mathrm{CN}$. The liquid chromatographic system (Waters Associates) consisted of an M-720 system controller, an M-730 data module, an M-6000A solvent delivery system, and an M-441 UV/VIS absorbance detector. Thirty fractions were collected, lyophilized, and then resuspended in $500 \mu \mathrm{l}$ of water. Bioactive fractions were pooled and subjected to reverse-phase HPLC (rpHPLC). First we used a Nucleosil C18 column $(250 \times 4.6 \mathrm{~mm})$, applying a discontinuous linear gradient of water and $\mathrm{CH}_{3} \mathrm{CN}$ in $7.5 \mathrm{~mm}$ TFA $\left(10 \mathrm{~min} 0 \% \mathrm{CH}_{3} \mathrm{CN}\right.$ and then $0-60 \% \mathrm{CH}_{3} \mathrm{CN}$ over $60 \mathrm{~min}$ ). Approximately 60 fractions were collected, lyophilized, and redissolved in distilled water. Bioactive fractions were pooled and subjected to a second round of rpHPLC using a narrow bore Nucleosil column $(250 \times 2.1 \mathrm{~mm})$, applying a discontinuous linear gradient of water and $\mathrm{CH}_{3} \mathrm{CN}$ in $0.05 \% \mathrm{HCl}\left(10 \mathrm{~min} 0 \% \mathrm{CH}_{3} \mathrm{CN}\right.$ and then $0-60 \% \mathrm{CH}_{3} \mathrm{CN}$ over $60 \mathrm{~min}$ ). Bioactive fractions from this rpHPLC run were rechromatographed with the same column and solvents but with a shallower gradient $\left(12 \% \mathrm{CH}_{3} \mathrm{CN}\right.$ over $10 \mathrm{~min}$ and then $12-24 \% \mathrm{CH}_{3} \mathrm{CN}$ over $40 \mathrm{~min}$ ) using a Gynotek system that consisted of a $480 \mathrm{G}$ gradient pump, a model III channel on-line degasser, and a UVD $320 \mathrm{~S}$ photo-diode array detector.

Peptide sequence determination and synthesis. Amino acid sequences were determined with a pulse liquid automatic sequencer (model 473A, Applied Biosystems, Foster City, CA) as described previously (Li et al., 1993). Peptides were synthesized by Fluorenylmethoxycarbonyl and t-butoxycarbonyl chemistry on an ABI 432A peptide synthesizer.

Mass spectrometry. Mass spectral analyses were performed on a Quattro-II triple-quadrupole mass spectrometer equipped with an electrospray source (Micromass). The first quadrupole (ms 1) was used for the mass measurement of the peptide and the parent ion selection for tandem mass spectrometry. For parent ion selection, the first quadrupole was set to transmit a mass window of $2.5 \mathrm{Da}$. The $(\mathrm{M}+\mathrm{H})^{2+}$ ion species was selected for fragmentation. The collision cell pressure was set at $3.3 \mathrm{mB}$ throughout the run, and the collision voltage was set to $15 \mathrm{~V}$. Argon was used as the collision gas. The quadrupole analyzer (ms 2) was scanned over the range of 50-1000 mass to charge $(\mathrm{m} / \mathrm{z})$. The resolution was set to $\sim 1000$.

\section{RESULTS cDNA cloning}

The degenerate oligonucleotide primers S1 and A1 were used to obtain a PCR product, named GRL104 (see Materials and Methods). GRL104, when analyzed and compared against the GenBank protein database, showed high (25-32\%) identical amino acid homology to a number of G-protein-coupled neuropeptide receptors. An oligonucleotide primer specific to GRL104 was used in conjunction with pBluescript forward and reverse arm primers in a PCR reaction on the cDNA CNS library to generate a larger GRL104 PCR product containing the full-length 5' region. If Lymnaea neuropeptide receptors are similar to those cloned from other species, then the distance from the exact primer to the $5^{\prime}$ end should be in the region of 1000-1500 bp. Bands in this size range were cloned into a pBluescript plasmid and transformed into DH5 $\alpha$. Plasmids isolated from two colonies were fully sequenced to identify the start methionine of GRL104. A candidate for a start methionine was found in one of the GRL104 clones, and this clone was isolated from the library by PCR screening (Bloem and Yu, 1990). The DNA sequence of the clone GRL104 is shown in Figure 1. 
CCTCGGATAATTTAGAGCTGTCGCTTGAAAACCATGGAACATAATGTGACTTATGTATGAAGC CATGAGAGTAGCGGGACCTTTGCCCATGAAACATGGGGATTGTGAGAAGGTCACGGACCT GTAACATATTCTT TGAAGGACAGTTAACTCGTTAATCTGAAGAAAAAGTTACCTGATGACTCT TCT T TAAAGGAAATCAAGTTTAGTTGTATGACTCTTAATCGCTGAGGATCAAATGTAACTACA CTGGTGGAGGCTGCAATGATTCGAACTCTTTCCTCTTTCAGCCAGGGCTAGCGCTCTATCGGT TTTGTTTTTTTTACCACTTTTATTCCTGGACGTGGATTTAAAGTTTTTTTTTACTTAACATG Met

TCTCAAATCGAGTCGATGTCCGAGCAGGCTGCGGTCATCTTCATCGAGCAGGCCAACCAGGAC SerGlnIIeGluSerMetSerGluGInAl aAl aval I le Phe I eGluGInAl aAsnGlnAsp

CTGGACAACGTCAGCGGCAATGACGTCAGCAGTTTCTTCTATAACGAAACGACGACCTTGTTC LeuAspAsnval SerGlyAsnAspvalSerSerPhePheTyrAsnGluThrThrThrLeuPhe CCGGGCAGCAACGAGAGCTTCGTGATGCCCPACGACGTGCCCACGGGGCTGATCTGCCTCCTG ProGlySerAsngluSerPheValMetProTyrAspValProThrGlyLeuI leCys LeuLeu GCGTTCCTGTACGGCTCCATCTCGCTGCTGGCCGTCATAGGCAACGGGCTGGTCATACTGGTC AlaPheLeuTyrGlySerIleSerLeuLeuAlaVa.I I IeGlyAsnGlyLeuValI le LeuVal ATCGTGAAGAACAGGAGGATGCACACGG I

ATCGTGAAGAACAGGAGGATGCACACGGTGACCAACATCTTCATCGCCAACCTGGCCGTGTCG I leValLysAsnArgArgMetHisThrValThrAsnile PheTleAlaAsnLeuAlaValser GACGTTATCATCGGCTTGTTTTCCATACCTTTCAGTTCCAAGCGGCCCT TCTGCAGCGCTGG AspValI leI leGlyLeuPheSerIleProPheGInPheGInAlaAlaLeuLeuGlnArgTrp GTGCTGGCCAACTTCATGTGCTCGCTGGCCCCCTTCGTCCAGGTGGTCAGCGTCAACGTCAGC Val LeuAl aAsnPheMe tCys SerLeuAlaProPheValGlnValValSerValAsnValser - L LII ATCTTCACGCTCAGCGTCATCGCCGTGGACCGCTACATCGCCGTCATCCACCCGTTCAAGGCC I lePheThrLeuSerValI leAlaValAspArgTyrIleAlaValIleHisProPheLysAla GGCTGCPCCAAGAAGTCGGCGGCCATCATCATCAGCATCATCTGGGCCGTCGGGATCGGCGCC GlyCysSerLys Lys SerAlaAlaIleIleI le SerIleI le TrpAlavalGlyI leGlyAla GCGCTTCCGGTGCCGCTGTTCTACTGGGTGGAGGACCTCACCGAGAACAACATCGTGATCCCC AlaLeuProval ProLeuPheTyrTrpValGluAspLeuThrGluAsnAsn I eVal I lePro AGGTGCGACTGGCACGCGCCGGACAACTGGCTGGATTTTCACCTGTATTACAACACGCTGCTG ArgCysAspTrpHisAlaProAspAsnTrpLeuAsp Phe His LeuTyrTyrAsnThr LeuLeu GTGTGTTTCCAGTACCTGCTGCCCCTGGTCATCATCACCTACTGTTACTGCCGGATAGCCTGG 1134 ValCysPheGlnTyrLeuLeuProLeuValIleIleThrTyrCysTyrCysArgIleAlaTrp 253 $\mathrm{V}$ CATATCTGGGGGTCACGGCGACCTGGCGCCCACGTGACCACTGAGGACGTCAGGGGACGTAAC 1197 HisI leTrpGlySerArgArgProGlyAlaHisValThrThrGluAspValArgGlyArgAsn

AAGCGAAAGGTCGTAAAGATGATGATCATCGTCGTCTGCCTGTTCGTCCTCTGCTGGCTGCCG 1260 LysArgLysValValLysMetMetIleIleValValCysLeuPheValLeuCysTrpLeuPro 295 CTCCAGATGTACAACCTGTTGCACAACATCAACCCGCTCATCAACCACTACCATTACATCAAC 1323 LeuGlnMet TyrAsnLeuLeuHisAsnIleAsnProLeuIleAsnHisTyrHisTyrIleAsn 316 VI

ATCATCTGGTTTCGTCCAATTGGCTGGCCATGAGCAACTCTTGCTACAACCCTTTCATCTAC 1386 IleIleTrpPheSerSerAsnTrpLeuAlaMetSerAsnSerCysTyrAsnPropheIleTyr 337 GGCCTCTTGAATGAAAAGT TCAAACGTGAGTTTCACCAGCTGTTCGTCATGTGTCCGTGCTGG 1449 GlyLeuLeuAsnGluLysPheLysArgGluPheHisGlnLeuPheValMetCysProCysTrp 253 VII

AAGGCGCGCGTCGACTACTACACGGAGTACTTCTCCGAGGACGCCAACATCTGCCGGCGCGCC 1512 LysAlaArgValAspTyrTyrThrGluTyrPheSerGluAspAlaAsnIleCysArgArgAla 379

AACACCAACGGTCACTGCCCGGCCAACAGGCACGGGGCGGTNGGTACAACTTCTACCGAGACG 1575 AsnThrAsnGlyHisCysProAlaAsnArgHisGlyAlaValGlyThrThrSerThrGluThr $\mathbf{4 0 0}$ ACAAGAAAGTCTATGCTAAGCAGGTCCAGGTGCAAGCGGACGAGACGGAGACGTCAAACATAT 1638 ThrArgLys SerMetLeuSerArgSerArgCysLysArgThrArgArgArgArgGlnThrTyr 421 GACGAAAGAAGAGAGACGTCATCCTGAAAATGACGTCCTACGTTTGAGAGGGCGCGACGGTG 1701 AspgluArgArgGluThrserser . 429
63

126

189

252
315

441 22

504 43 567 64 630 85 106 127 819 882 169 945 190 008 11 32

\section{3} 74 5

6

,

49

3

西

Figure 1. Nucleotide and deduced amino acid
sequence of Lymnaea GRL104 receptor cDNA sequence of Lymnaea GRL104 receptor cDNA
cloned in pBluescript $\mathrm{BS}^{-}$. A methionine at posicloned in pBluescript $\mathrm{BS}^{-}$. A methionine at posi-
tion 374 indicates the start of the open reading
frame of $1287 \mathrm{bp}$, which translates into 429 amino acids. Putative transmembrane regions are underlined and labeled I-VII. Cysteines suspected of being involved in a cysteine bridge between extracellular loops 2 and 3 are indicated by filled circles. Arrowheads indicate possible N-linked glycosylation sites. The nucleotide sequence for GRL104 has been deposited into GenBank, accession number U84499.

\section{Analysis of GRL104}

The complete sequence of GRL104 was entered into DNASTAR so that it could be analyzed for open reading frames (ORF). A methionine at position 374 signaled the beginning of the longest ORF, of $1287 \mathrm{bp}$, which translates into 429 amino acids, and this was taken to be the coding ORF (Fig. 1). To obtain further information about GRL104, we analyzed the amount of the sequence homology between the full-length amino acid sequence of GRL104 and other G-protein-coupled receptors. The full amino acid sequence resulting from the ORF in the cDNA GRL104 was compared against protein 
TM III

\begin{tabular}{|c|c|c|}
\hline SK & FQNLFPITAMFVIS & IYSMTAIAADR \\
\hline SP & FHNEFPIAALFAS & IYSMTAVAFDRY \\
\hline JPY & FVNYSQAVSVLVS & AYTLVAIS TDRY \\
\hline USC & LWLAIDYVASNA & VLNLLIISADR \\
\hline & IWVAFDIMCSTAS & I LNLCVISUDRY \\
\hline & IWLSSDITCCTA & ILHLCVIAIDR \\
\hline RL104 & LAPEVQVVSNVVIS & IFTLSVIAVD \\
\hline
\end{tabular}

SK

SP

NPY

MUSC

DA

$5 \mathrm{HT}$

GRL104
TM VI

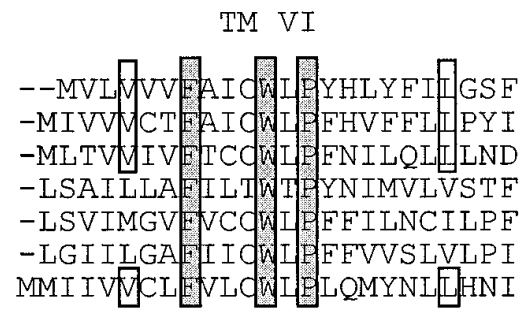

TM IV

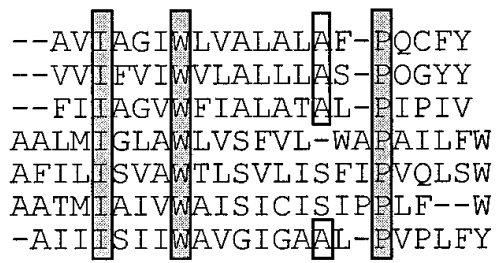

TM VII

-VYLALFW LAMSS TM NWI I I CCL

-VYLASMW LAMSSTM THA I I MCL

- VWFAFHW LAMSHCOSNOII I CY

-LWELGYWLCYVNST INPMCYALC

-TEDVFVWEGWANSSLNPI I AAF

- LFDFFTWLGYLNSLINEI I ITVD

IIWFSSNW LAMSNSC UWE WIMLL

Figure 2. Shown are transmembrane (TM) region amino acid alignments between GRL104 and other G-protein-coupled receptors: SK, human substance K receptor (Gerard et al., 1990); SP, rat substance P receptor (Yokota et al., 1989); NPY, human NPY Y1 receptor (Herzog et al., 1992); Musc, human m1 ACh receptor (Peralta et al., 1987); DA, human D1 dopamine receptor (Dearry et al., 1990); 5HT, human 5HT1d receptor (Hamblin and Metcalf, 1991). Shaded boxes indicate residues that are conserved among both classical and peptide receptors. Nonshaded boxes indicate residues that are conserved only among peptide receptors.

databases with the DNASTAR program Proscan, which uses the algorithm of Lipman and Pearson to compare amino acid sequence similarities between proteins (Lipman and Pearson, 1985). The protein database search for GRL104 yielded neuropeptide receptors as the top 20 most similar proteins. Specifically, the rat neuropeptide $Y$ (NPY) Y1 receptor was the most similar, with the exact amino acid homology being $32.4 \%$ on a 355 amino acid overlap. When the amino acid sequence was analyzed for its hydrophobicity profile (Kyte and Doolittle, 1982), it was found that there were seven regions of hydrophobicity that could be transmembrane domains. There were several domains that had particularly high homology to the rat NPY receptor; these areas closely correlated with the hydrophobic, and thus possibly the transmembrane, domains. In addition to the seven transmembrane domains, GRL104 has a very short extracellular region of only 45 amino acids. At the C-terminal cytosolic end of the receptor there is an 89 amino acid stretch.

Comparisons were made between some of the transmembrane regions in a selection of classical neurotransmitter receptors, neuropeptide receptors, and this Lymnaea receptor GRL104. This alignment is shown in Figure 2. GRL104 shows sequence homology to both classical and peptide G-protein-coupled receptors, e.g., the serine and aspartate arginine tyrosine triplet in TM III, the isoleucine and proline in TM IV, the phenylalanine tryptophan and proline in TM VI, and the tryptophan, the asparagine proline doublet, and the tyrosine in TM VII. Further sequence homology is present between GRL104 and neuropeptide receptors alone in that there is a conserved leucine in TM VI, a conserved alanine in TM IV, and a conserved tyrosine in TM VII. These alignments indicated that GRL104 was likely to be a G-protein-coupled neuropeptide receptor.

\section{Generation of stable CHO-K1 cell lines}

GRL104 was modified as described in Materials and Methods, and the resulting plasmid, pcD104, was used in transfection experiments. $\mathrm{CHO}-\mathrm{K} 1$ cells were transfected with pcD104, and nine clones were picked for further experiments. To confirm that the plasmid pcD104 had been integrated into the $\mathrm{CHO}$ genomic DNA, we analyzed some of these cell lines by PCR. Sense and antisense primers at the

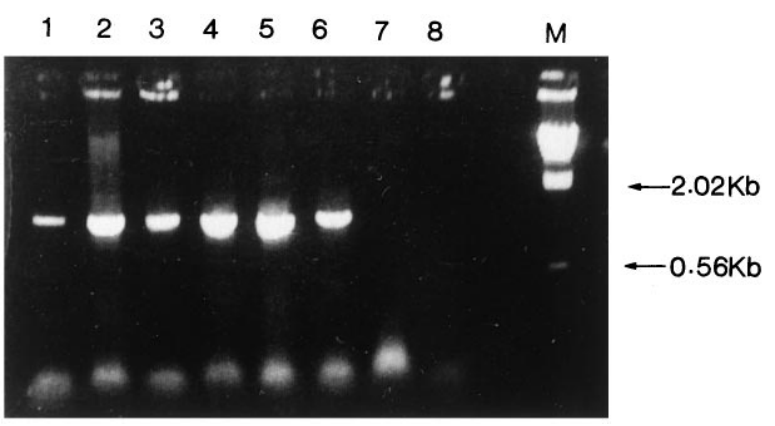

Figure 3. PCR analysis of CHO cell lines stably transfected with pcD104, using primers specific to pcD104. Lanes 1-6 contain PCR products from $\mathrm{CHO}$ cell lines $\mathrm{KC} 2, \mathrm{KC} 4, \mathrm{KC} 5, \mathrm{KC} 6, \mathrm{KC} 7$, and $\mathrm{KC} 9$. Lane 7 is a negative control using untransfected $\mathrm{CHO}-\mathrm{K} 1$ cells as template. Lane 8 is a control PCR reaction with no template. Lane $M$ contains size markers generated from $\lambda$ bacteriophage cut by HindIII.

extreme $5^{\prime}$ and $3^{\prime}$ ends of the ORF of pcD104 were used to attempt to amplify the receptor DNA sequence from the cell lines. All the $\mathrm{CHO}$ lines tested, $\mathrm{KC}$, $\mathrm{KC} 4, \mathrm{KC} 5, \mathrm{KC} 6, \mathrm{KC} 7$, and $\mathrm{KC}$, gave $\mathrm{PCR}$ products of $\sim 1300 \mathrm{bp}$, which is the expected size for the GRL104 transcript (Fig. 3). From this it could be inferred that the transfected $\mathrm{CHO}$ cells had incorporated pcD104 into the $\mathrm{CHO}$ genome. These clones were now called GRL104 CHO cell lines, because pcD104 was carrying GRL104 receptor DNA.

\section{Expression of GRL104 in mammalian cells and identification of the endogenous ligand}

On binding to ligands, many G-protein-coupled receptors, including peptide receptors, link via G-proteins in a second messenger cascade, resulting in an increase in intracellular calcium concentration. This can be used to assay for ligands to GRL104. The first stage was to challenge the GRL104 CHO cell lines with a CNS peptide extract from Lymnaea. Peptides from 500 Lymnaea CNS were extracted and purified through a C18 solid-phase extraction column. All nine GRL104 CHO cell lines, together with untransfected CHO cells, were loaded with Fura- 2 and challenged with an amount of crude 


\begin{tabular}{|c|c|c|c|}
\hline Species & Peptide name & Amino acid sequence & Reference \\
\hline Lymnaea stagnalis & Lymnokinin & PSFHSWS-amide & This paper \\
\hline \multirow[t]{8}{*}{ Leucophaera maderae } & Leucokinin I & DPAFNSWG-amide & Holman et al., 1986a \\
\hline & Leucokinin II & DPGFSSWG-amide & Holman et al., 1986a \\
\hline & Leucokinin III & DQGFNSWG-amide & Holman et al., 1986b \\
\hline & Leucokinin IV & DASFHSWG-amide & Holman et al., 1986b \\
\hline & Leucokinin V & GSGFSSWG-amide & Holman et al., 1987a \\
\hline & Leucokinin VI & pESSFHSWG-amide & Holman et al., 1987a \\
\hline & Leucokinin VII & DPAFSSWG-amide & Holman et al., 1987b \\
\hline & Leucokinin VIII & GADFYSWG-amide & Holman et al., 1987b \\
\hline \multirow[t]{5}{*}{ Acheta domesticus } & Achetakinin I & SGADFYPWG-amide & Holman et al., 1990 \\
\hline & Achetakinin II & AYFSPWG-amide & Holman et al., 1990 \\
\hline & Achetakinin III & ALPFSPWG-amide & Holman et al., 1990 \\
\hline & Achetakinin IV & NFKFNPWG-amide & Holman et al., 1990 \\
\hline & Achetakinin V & AFHSWG-amide & Holman et al., 1990 \\
\hline Locusta migratoria & Locustakinin & AFSSWG-amide & Schoofs et al., 1992 \\
\hline \multirow[t]{3}{*}{ Culex salinarius } & CDP I & NPFHSWG-amide & Clottens et al., 1993 \\
\hline & CDP II & NNANVFYPWG-amide & Clottens et al., 1993 \\
\hline & CDP III & TKYVSKQFFSWG-amide & Clottens et al., 1993 \\
\hline \multirow[t]{3}{*}{ Aedes aegypti } & I & NSKYVSKQKFYSWG-amide & Veenstra, 1994 \\
\hline & II & NPFHAYFSAWG-amide & Veenstra, 1994 \\
\hline & III & NNPNVFYPWG-amide & Veenstra, 1994 \\
\hline \multirow[t]{3}{*}{ Helicoverpa zea } & Helicokinin I & YFSPWG-amide & Blackburn et al., 1995 \\
\hline & Helicokinin II & VRFSPWG-amide & Blackburn et al., 1995 \\
\hline & Helicokinin III & KVKFSAWG-amide & Blackburn et al., 1995 \\
\hline
\end{tabular}

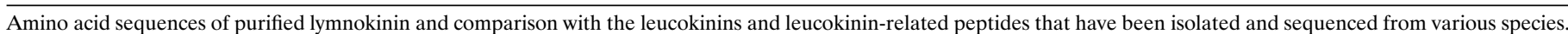
Amino acids that are conserved throughout the family are in bold.

peptides equivalent to two CNS. Changes in intracellular calcium were monitored by studying changes in fluorescence. Five of the nine clones responded to the peptide extract, although the other four did not respond. Untransfected CHO cells did not respond to Lymnaea CNS peptide extracts. These results suggested that in over $50 \%$ of the stable cell lines, where the receptor construct had incorporated into the $\mathrm{CHO}$ genome, it was transcribed and, subsequently, translated. Moreover, the results demonstrate that the GRL104 receptor in $\mathrm{CHO}$ cells was able to couple to a second messenger system, which had the effect of increasing intracellular calcium. The $\mathrm{CHO}$ clone GLR104 KC6 was used in subsequent assays because, of the nine GRL104 CHO stable cell lines, it yielded the largest rise in intracellular calcium when challenged with the CNS peptide extract.

Figure 4 shows the four steps of the HPLC procedure. Fractions 23 and 24 from the gel permeation separation were bioactive in the calcium assay (Fig. $4 A$ ) and so were combined and run on the rpHPLC column in step 2 (Fig. $4 B$ ). Fraction 29 was positive and further purified in step 3 on a reverse-phase HPLC column (Fig. $4 C$ ). Fraction 37 from this run generated a rise in intracellular calcium concentration, and fraction 36 gave a much smaller rise. A final rpHPLC purification run (step 4, Fig. 4D) was performed on pooled fractions 36 and 37 (from step 3), which resolved into two peaks from which it was possible to obtain peptide sequence from both peaks. Edman sequencing revealed one of the peptides to be GDPFLR (the large peak). It is very likely that this peptide represents the previously reported GDPFLRFamide, in which the C-terminal amino acid was washed off from the sequencing filter and cannot be detected. The other peptide (the small peak) was deduced to have the sequence PSFHSWX. As with GDPFLRFamide, the first six residues could be assigned unambiguously; however, the final residue in this peptide was evident only as a small peak (again as with GDPFLRFamide the C-terminal residue also may have been washed off) and could not be assigned with complete confidence. The sequence PSFHSW was run through a peptide database to establish whether it had any homology to known peptides. This search produced a family of eight peptides, all eight amino acids long, called the leucokinins (Table 1); therefore, we designated the Lymnaea peptide lymnokinin. In an attempt to confirm the sequence of lymnokinin, we isolated and sequenced a new batch of peptide. On this occasion closer inspection of the sequencing data indicated the presence of a $(\mathrm{C}$ terminal) serine residue. To ascertain the sequence of the peptide unequivocally, we subjected it to tandem mass spectrometric analysis. Figure 5 shows that the peptide is PSFHSWSamide.

One of the potential ligands, GDPFLRFamide, was unable to stimulate GRL104 even at micromolar concentrations (data not shown). Synthetic lymnokinin, on the other hand, was able to stimulate $\mathrm{CHO}$ cells expressing GRL104 at physiological concentrations, and a dose-response experiment was performed (Fig. 6). Lymnokinin had an $\mathrm{EC}_{50}$ of $1.14 \mathrm{nM}$, which is similar to other neuropeptide potencies. For instance, $\mathrm{SP}$ has an $\mathrm{IC}_{50}$ of $\sim 1 \mathrm{~nm}$ (Hershey and Krause, 1990) for the NK-1 receptor. Because it seemed likely that lymnokinin was indeed a member of the leucokinin family, it was possible that other members of the family also were able to elicit calcium responses in CHO cells expressing GRL104. Three commercial preparations of the insect leucokinins were tested on KC6. Leucokinin IV and leucokinin VI, both of which have five of the last six C-terminal amino acids in common with lymnokinin (Table 1), were able to elicit an increase in calcium concentration in GRL104 KC6 CHO cells at $100 \mathrm{~nm}$ or above, i.e., a 100-fold lower potency than lymnokinin, whereas leucokinin $\mathrm{V}$, which only has three amino acids in common with lymnokinin (Table 1), was less potent, being 
A

$\mathbf{A}_{1}$

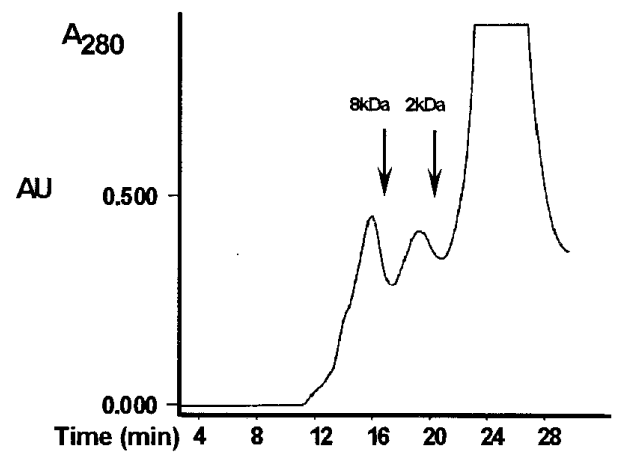

$A_{2}$

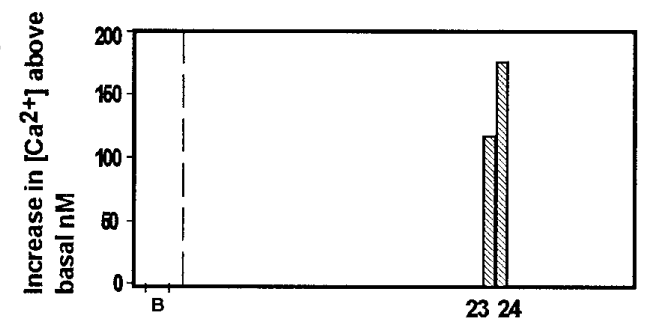

B

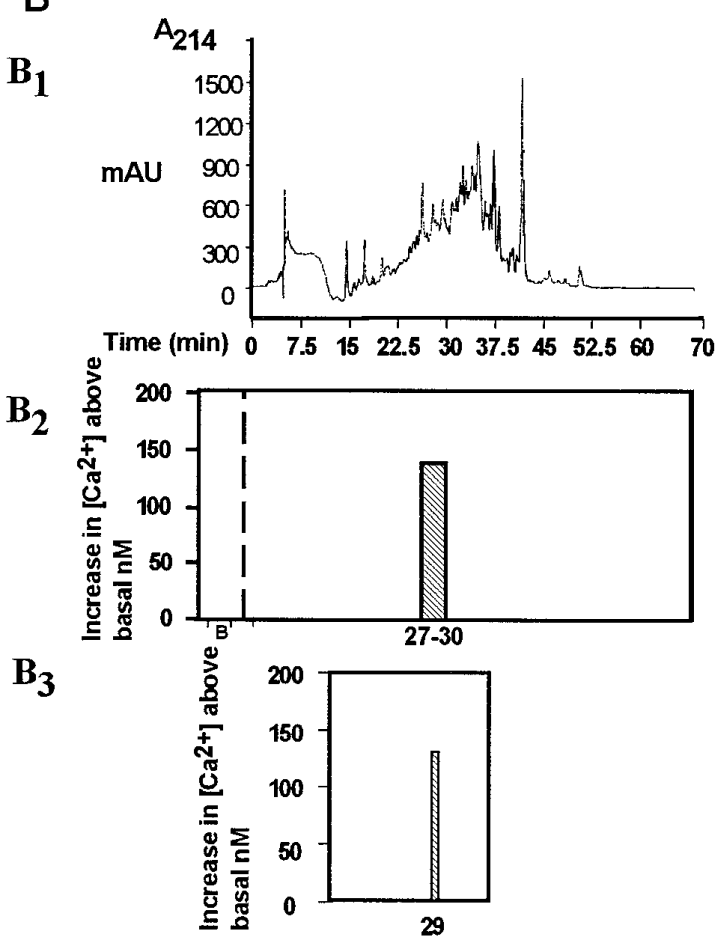

C

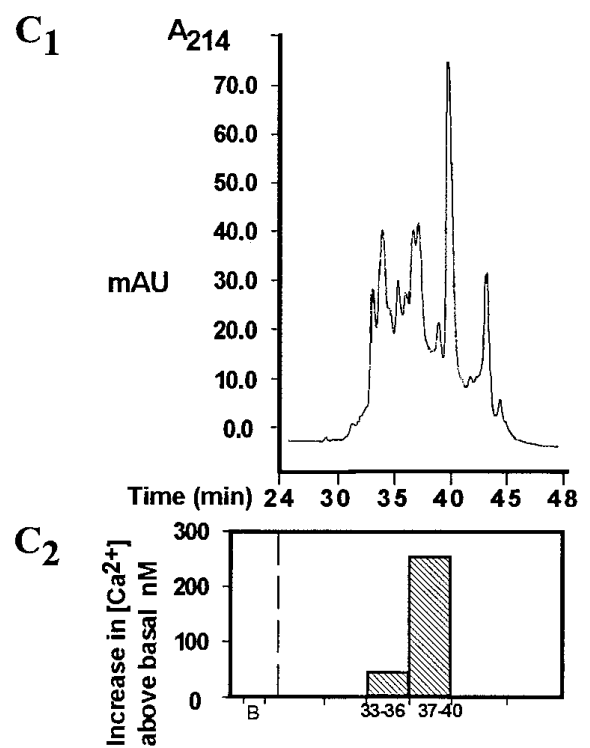

$\mathrm{C}_{3}$

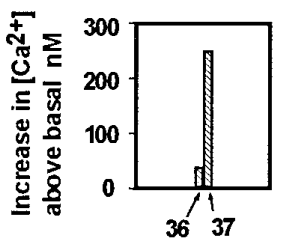

D

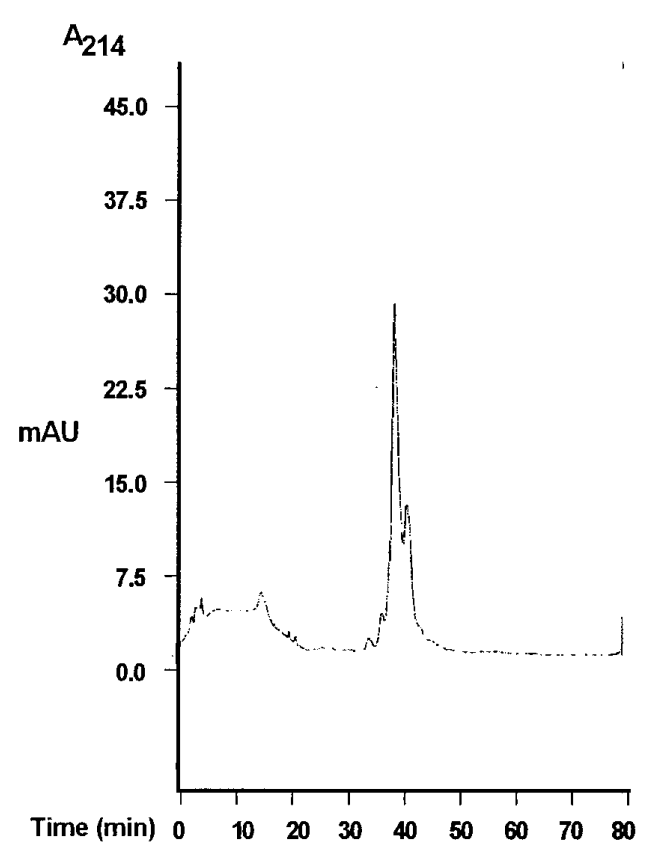

Figure 4. Purification of the endogenous ligand for GRL104. All assays were performed on a CHO cell line that had been stably transfected with pcD104 cDNA (CHO cell line GRL104 KC6). The top of each panel, $A-C$, gives the chromatogram for the HPLC purification indicated. $A_{l}$, HPGPC fractionation of an extract of 500 Lymnaea brains; $B_{1}$, rpHPLC fractionation of combined fractions 23 and 24 from $A$; $C_{1}$, rpHPLC fractionation of fraction 29 from $B$. $D$, rpHPLC fractionation of combined fractions 36 and 37 from $C$. The bottom of each panel, $A-C$, shows the effect of the indicated HPLC fractions on intracellular calcium levels in the CHO cell line GRL104 KC6, using 2, 4, and 8 CNS equivalents for $A_{2}, B_{2}, B_{3}, C_{2}$, and $C_{3}$, respectively. $x$-Axis numbers indicate HPLC fraction number. The calcium increases were calculated as increases in concentration above basal levels. On each HPLC fractionation, $A_{2}$ shows the two fractions (of 33) that were active (mean of two determinations), $B_{3}$ shows the fraction (of 54) that was active (mean of two determinations), and $C_{3}$ shows the two fractions (of 45) that were active (one determination only to conserve enough of the fraction for the next stage of HPLC, seen in $D$ ). 


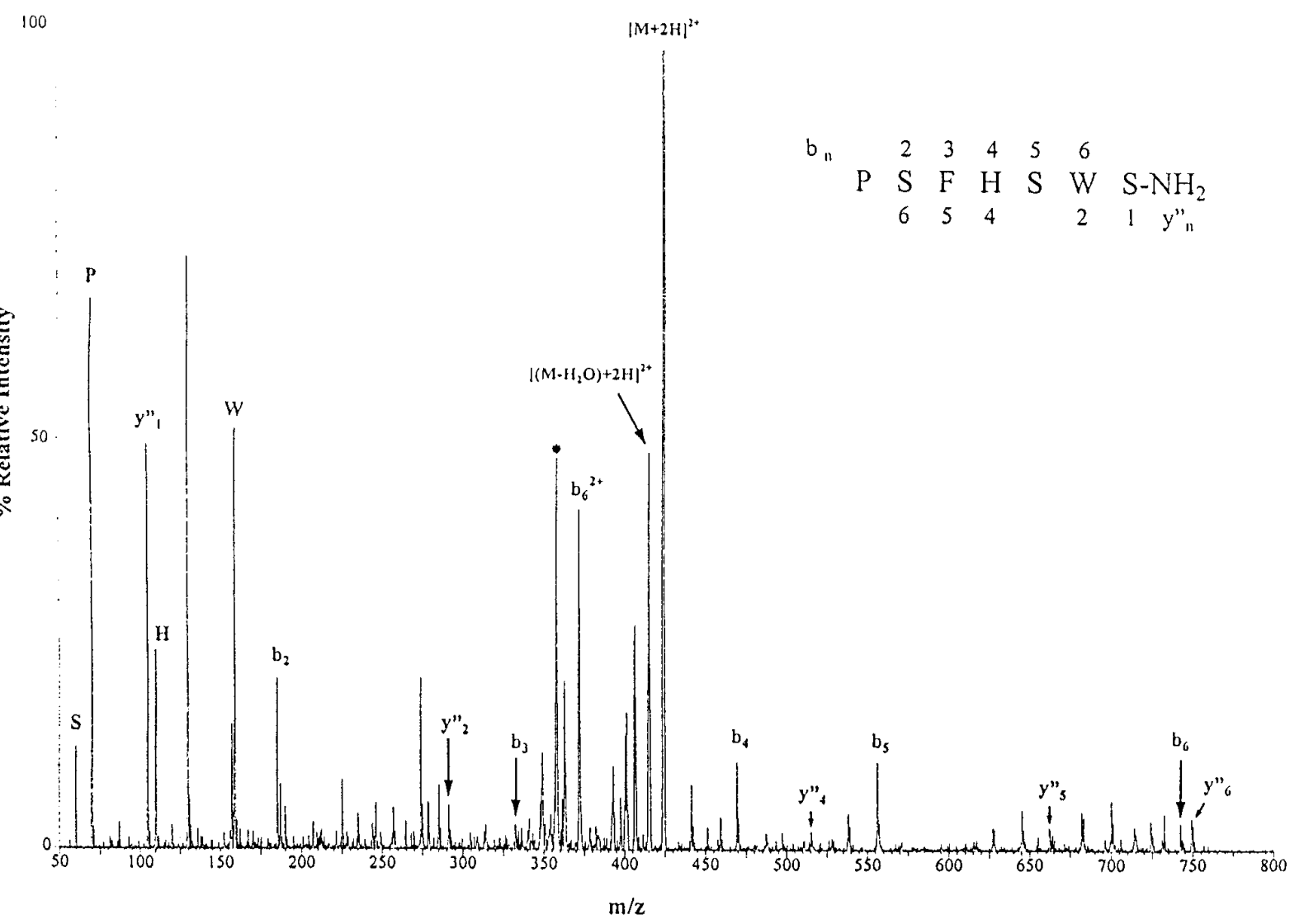

Figure 5. Tandem mass spectrometric analysis of lymnokinin. Averaged daughter ion spectra of the purified lymnokinin, generated from the doubly charged parent ion species $(\mathrm{M}+2 \mathrm{H})^{2+}$ of $\mathrm{m} / \mathrm{z} 424 \mathrm{Da}$. The Roepstorff nomenclature is used to identify fragment ions (Roepstorff and Fohlman, 1984). The $y$ " ions are formed by charge retention on C-terminal fragments, and the a and b ions are formed on N-terminal fragments. The measured protonated mass of the peptide [846.8 Da, as detected in stage 1 (ms 1) of the tandem MS analysis; data not shown] as well as the $\mathrm{y}^{\prime \prime}$, a, and b ion series are in perfect agreement with the calculated protonated masses of the peptide PSFHSWSamide (846.9 Da as detected in ms 1; data not shown) and the corresponding $\mathrm{y}$, $\mathrm{a}$, and $\mathrm{b}$ ion series. The asterisk represents $\mathrm{a}_{6}{ }^{2+}, x$-axis; $m / z$ is mass to charge ratio.

able to elicit a response at $1 \mu \mathrm{M}$ or above (data not shown). On the other hand, PSFHSWGamide, which is identical to lymnokinin apart from the Gamide (which is present in the leucokinins), was as potent as lymnokinin with an $\mathrm{EC}_{50}$ of $1.2 \mathrm{nM}$ (data not shown). Several other peptides (VIP, FLRFamide, FMRFamide, APGWamide, vasopressin, substance $\mathrm{P}$, substance $\mathrm{K}$, eloidisin, and neuropeptide $\mathrm{Y}$ ) were tested on GRL104 but were unable to elicit any calcium response.

\section{DISCUSSION}

The leucokinin family of peptides (Table 1) has been the focus of considerable interest since they were first isolated from the cockroach and, subsequently, in other insects such as the cricket, locust, and mosquito. They have two main physiological effects on insects; one is to increase hindgut motility in cockroaches (Holman et al., 1986a,b, 1987a,b), and the other is an involvement in insect diuresis (Hayes et al., 1989; Coast et al., 1990). It has been shown that leucokinins have an effect on the transepithelial voltage and the fluid secretion of isolated Malpighian tubules of the yellow fever mosquito Aedes aegypti, and this effect is speculated to be mediated by an increase in chloride ion permeability of epithelial membranes (Hayes et al., 1989; Pannabecker et al., 1993). Leucokinin-like peptides have effects on the stomatogastric nervous system of the crab Cancer borealis; this work shows that individual leucokinins were able to excite the pyloric rhythm and also the DG neuron (which is involved in the gastric mill rhythm), suggesting the presence of an as yet uncharacterized endogenous leucokinin-like peptide in this species

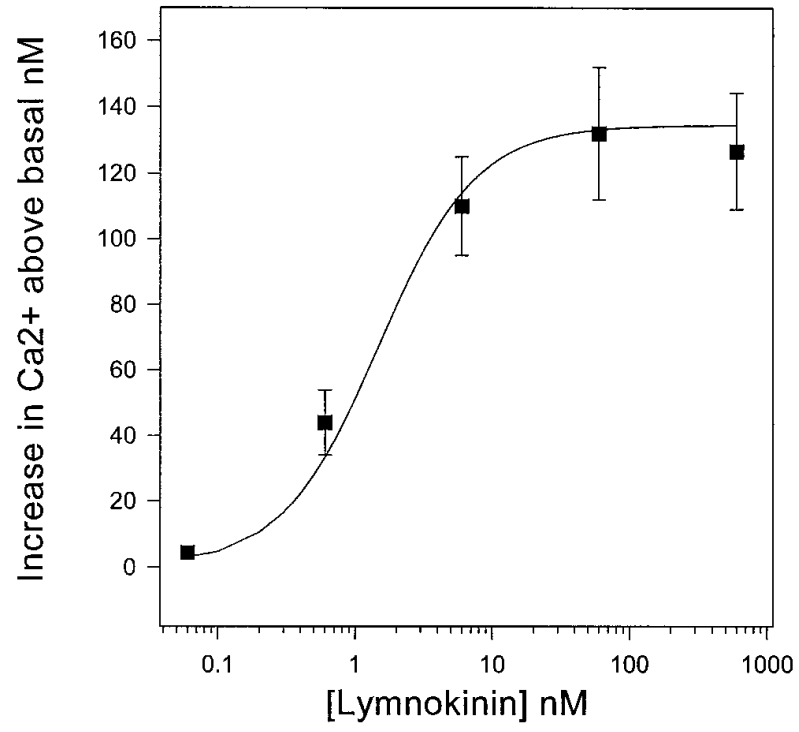

Figure 6. Dose-response curve of the increase in intracellular calcium in GRL104 KC6 CHO cells elicited by synthetic lymnokinin. The calcium increases were calculated as increases in concentration above basal calcium levels. Each data point is the mean of three separate determinations. Error bars are \pm SD. 
(Blitz et al., 1995). In Helix, an antibody to leucokinin I stained many neurons in the CNS, including interneurons and neurons that are known to innervate peripheral organs, indicating that leucokinins play a wide role in the CNS of molluscs (Elekes et al., 1994). The identification and characterization of the molluscan leucokininrelated receptor GRL104 described here is an important advance in mapping leucokinin neuronal pathways and understanding the physiological function of this family of peptides in molluscs and, potentially, in other invertebrates. Work is currently in progress to localize, in alternate sections of the Lymnaea CNS, the relationship between the lymnokinin receptor-expressing cells (using in situ hybridization) and lymnokinin (using an antiserum raised against leucokinin IV).

The G-protein-coupled superfamily of receptors (Probst et al., 1992 ) is composed of a number of subfamilies, one of which is the peptide receptor family. Members of this group include, for instance, the NPY receptors and the tachykinin receptors, which comprise further subfamilies of receptors. GRL104 was most similar to neuropeptide receptors, especially to the rat NPY receptor with $32 \%$ identical sequence homology. This amount of homology indicates that GRL104 is very likely to be a neuropeptide receptor, but not a subtype of any known neuropeptide receptor. This, in conjunction with the fact that none of the tachykinins or NPY or any other peptide tested (except leucokinins) were able to mobilize calcium in $\mathrm{CHO}$ cells transfected with GRL104, indicates that GRL104 is the first example of a new group of G-protein-coupled neuropeptide receptors.

Of the peptides tested, only PSFHSWSamide (lymnokinin) and PSFHSWGamide were able to activate GRL104 at the nanomolar level. We consider that lymnokinin is the endogenous ligand to GRL104 because it was isolated from the CNS of Lymnaea, but we cannot rule out that PSFHSWGamide also may be present in the CNS of Lymnaea and a ligand for GRL104. Furthermore, it is possible that other presumably lymnokinin-like peptides are in the CNS of Lymnaea that are also ligands for GRL104. Efficacious peptides present in the CNS at very low levels would not be isolated using the above HPLC approach in which only 500 Lymnaea CNS were used; it may be that, as in the case of the leucokinins, lymnokinin may be just one of a family of lymnokinin-like peptides. It is interesting to note that members of the leucokinin group of peptides also were able to activate GRL104. Two obvious candidates were leucokinin IV and leucokinin VI, because they have five of the last six C-terminal amino acids in common with the deduced sequence of lymnokinin. These peptides activated GRL104 at $500 \mathrm{~nm}$. Apart from the C-terminal residue, the only differences between lymnokinin and leucokinin IV and leucokinin VI are that the latter two peptides have one extra amino acid and that the amino acid at position seven is an alanine for leucokinin IV and a serine for leucokinin VI, whereas for lymnokinin it is a proline. One of the other members of the leucokinin peptide family, leucokinin V, was tested on GRL104, eliciting a functional response only at $10^{-6} \mathrm{M}$. This comparatively lower potency is perhaps not surprising considering that only three amino acids were in common (Table 1). It is probable that the other peptides shown in Table 1, apart from achetakinin $\mathrm{V}$ and culekinindepolarizing peptide (CDP) I, which share similar C-terminal regions with lymnokinin, also would elicit a functional response in the micromolar range. In the light of the Gamide being invariant in the leucokinin peptide family, PSFHSWGamide was also synthesized and tested for functional efficacy with respect to GRL104. The fact that PSFHSWGamide has a very similar potency to lymnokinin indicates that the $\mathrm{C}$-terminal residue may not be critical in that it can be Gamide or Samide. This is perhaps not too surprising, because glycine and serine are very similar. Other peptides with little or no
C-terminal sequence homology to lymnokinin were unable to elicit any functional response. These data seem to suggest that lymnokinin $\mathrm{N}$-terminal residues are important for increased potency when coupling to GRL104, with the C-terminal residues perhaps playing a greater role in binding to the receptor. Further evidence indicating the importance of the $\mathrm{N}$-terminal region of neuropeptides with respect to functional potency has been provided previously by structure-activity studies with leucomyosuppressin, a 10-amino-acid-long peptide isolated from cockroach, which is able to inhibit spontaneous contractions of visceral muscles (Nachman et al., 1993). A clear relationship was found between $\mathrm{C}$-terminal peptide content and potency, with the last five $\mathrm{C}$-terminal amino acids being the minimum size for eliciting a functional response. As more residues were added from the $\mathrm{C}$-terminal end, potency increased. Binding studies with both $\mathrm{N}$ - and $\mathrm{C}$-terminally truncated lymnokinin analogs are needed to determine whether $\mathrm{N}$-terminal residues are responsible for the increased potency and the C-terminal end for binding to GRL104. Although not examined in the present work, the full dose-response characteristics of the leucokinins with respect to GRL104 also would be of interest regarding the relationship between peptide structure and function.

An apparent difference by a factor $\sim 50$ is evident between the potencies of the leucokinin-like peptides in the hindgut and Malpighian tubule assays, and lymnokinin in the calcium assays, with CHO cells expressing GRL104 receptor protein. For instance, the $\mathrm{ED}_{50}$ for achetakinin-I in the Malpighian tubule assay is $7.5 \times 10^{-11} \mathrm{M}$ (Coast et al., 1990), whereas the $\mathrm{EC}_{50}$ of lymnokinin with respect to GRL104 is 1.14 nM. This difference may indicate a combined hormonal/neurotransmitter role for lymnokinin, as has been suggested for the leucokinins (Muren et al., 1993). The fact that GRL104 was isolated from a CNS cDNA library is in agreement for its being the receptor for lymnokinin when this peptide is acting as a neurotransmitter in the CNS of Lymnaea, and, as has been mentioned previously, the $\mathrm{EC}_{50}$ of lymnokinin with respect to GRL104 is in the range found for other peptide neurotransmitters.

Here we have described the cloning from Lymnaea of a neuropeptide receptor, GRL104, for which the endogenous ligand lymnokinin, a leucokinin-like peptide, has been isolated. GRL104 represents the first example of a new subfamily of neuropeptide receptors, the leucokinin-like peptide receptors. Also presented here is the first example of the isolation of a leucokinin-like peptide in a invertebrate other than an insect. Molecular biological techniques such as PCR have enabled many G-protein-coupled receptor sequences, characterized as such purely on homology to known receptors, to be isolated. Many of these receptors are, however, "orphans," because the nature of the endogenous ligands is unknown. Recently, an approach using HPLC fractions on receptor-expressing cell lines was used to identify a novel opiate ligand to an orphan G-protein-coupled receptor, using a cAMP assay (Meunier et al., 1995; Reinscheid et al., 1995). The approach described in the present work (reported briefly previously, Tensen et al., 1994a), which also uses multistep HPLC but this time uses as the functional response an increase in intracellular calcium, is a more general method for isolating an endogenous ligand to a suspected G-protein-coupled receptor in that both cAMP and PKC second messenger pathways result in an increase in intracellular calcium. This approach should be valuable in identifying the ligands to other orphan receptors. 


\section{REFERENCES}

Benjamin PR, Burke JF (1994) Alternative mRNA splicing of the FMRFamide gene and its role in neuropeptidergic signalling in a defined network. BioEssays 16:335-342.

Blackburn MB, Wagner RM, Shasanowitz J, Kochansky JP, Hunt DF, Raina AK (1996) The isolation and identification of 3 diuretic kinins from the abdominal ventral nerve cord of adult Helicoverpa zea. J Insect Physiol 41:723-730.

Blitz DM, Christie AE, Marder EM, Nusbaum MP (1995) Distribution and effects of tachykinin-like peptides in the stomatogastric nervous system of the crab, Cancer borealis. J Comp Neurol 354:282-294.

Bloem LJ, Yu L (1990) A time-saving method for screening cDNA or genomic libraries. Nucleic Acids Res 18:2830.

Chen Y, Veenstra JA, Davis NT, Hagedorn HH (1994) A comparative study of leucokinin-immunoreactive neurons in insects. Cell Tissue Res 276:69-83.

Clottens FL, Meola SM, Coast GM, Hayes TK, Wright MS, Nachman RJ, Holman GM (1993) Characterization of an antiserum against an achetakinin I-analog and its use for the localization of culekinin depolarizing peptide II in the mosquito, Culex salinarius. Regul Pept 49:145-157.

Coast GM, Holman GM, Nachman RJ (1990) The diuretic activity of a series of cephalomyotropic neuropeptides, the achetakinins, on isolated Malpighian tubules of the house cricket, Acheta domesticus. J Insect Physiol 36:481-488.

Dearry A, Gingrich JA, Falardeau P, Fremeau RTJ, Caron MG (1990) Molecular cloning and expression of the gene for a human $\mathrm{D}_{1}$ dopamine receptor. Nature 347:72-76.

Elekes K, Hernadi L, Muren JE, Nassel DR (1994) Peptidergic neurons in the snail Helix pomatia: distribution of neurons in the central and peripheral nervous system that react with an antibody raised to the insect neuropeptide, leucokinin I. J Comp Neurol 341:257-272.

Gerard NP, Eddy RL, Shows TB, Gerard C (1990) The neurokinin A (substance K) receptor. J Biol Chem 265:20455-20462.

Grynkiewicz G, Poenie M, Tsien RY (1985) A new generation of $\mathrm{Ca}^{2+}$ indicators with greatly improved fluorescence properties. J Biol Chem 260:3440-3450.

Hamblin MW, Metcalf MA (1991) Primary structure and functional characterization of a human $5 \mathrm{HT}_{1 \mathrm{D}}$-type serotonin receptor. Mol Pharmacol 40:143-148.

Hayes TK, Pannabecker TL, Hinckley DJ, Holman GM, Nachman RJ, Petzel DH, Beyenbach KW (1989) Leucokinins, a new family of ion transport stimulators and inhibitors in insect Malpighian tubules. Life Sci 44:1259-1266.

Hershey D, Krause JE (1990) Molecular characterization of a functional cDNA encoding the rat substance P receptor. Science 247:958-962.

Herzog H, Hort YJ, Ball HT, Hayes G, Shine J, Selbie LA (1992) Cloned human neuropeptide $\mathrm{Y}$ receptor couples to 2 different 2 nd messenger systems. Proc Natl Acad Sci USA 89:5794-5798.

Holman GM, Cook BJ, Nachman RJ (1986a) Isolation, primary structure, and synthesis of two neuropeptides from Leucophaea maderae: members of a new family of cephalomyotropins. Comp Biochem Physiol C 84:205-211.

Holman GM, Cook BJ, Nachman RJ (1986b) Primary structure and synthesis of two additional neuropeptides from Leucophaea maderae: members of a new family of cephalomyotropins. Comp Biochem Physiol C 84:271-276.

Holman GM, Cook BJ, Nachman RJ (1987a) Isolation, primary structure, and synthesis of leucokinins V and VI: myotropic peptides of Leucophaea madera. Comp Biochem Physiol C 88:27-30.

Holman GM, Cook BJ, Nachman RJ (1987b) Isolation, primary structure, and synthesis of leucokinins VII and VIII: the final members of this new family of cephalomyotropic peptides isolated from head extracts of Leucophaea madera. Comp Biochem Physiol C 88:31-34.

Holman GM, Nachman RJ, Wright M (1990) A strategy for the isolation and structural characterization of certain insect myotropic peptides that modify the spontaneous contractions of the isolated cockroach hindgut. In: Chromatography and isolation of insect hormones and pheromones (McCaffery AR, Wilson, ID eds), pp 195-204. New York: Plenum.

Kozak M (1986) Point mutations define a sequence flanking the AUG initiator codon that modulates translation by eukaryotic ribosomes. Cell 44:283-292.

Kyte J, Doolittle RF (1982) A simple method for displaying the hydropathic character of a protein. J Mol Biol 157:105-132.

Li KW, Holling T, de With ND, Geraerts WPM (1993) Purification and characterization of a novel tetradecapeptide that modulates oesophagus motility in Lymnaea stagnalis. Biochem Biophys Res Commun 197:1056-1061.

Libert F, Parmentier M, Lefort A, Dinsart C, Van SJ, Maenhaut C, Simons MJ, Dumont JE, Vassart G (1989) Selective amplification and cloning of four new members of the $\mathrm{G}$ protein-coupled receptor family. Science 244:569-572.

Lipman DJ, Pearson WR (1985) Rapid and sensitive protein similarity searches. Science 227:1435-1441.

Lundquist CT, Brodin E, Muren JE, Nassel DR (1993) Tachykinin- and leucokinin-related peptides in the nervous system of the blowfly: immunocytochemical and chromatographical diversity. Peptides 22:1-20.

Meunier J-M, Mollereau C, Toll T, Suaudeau C, Molsand C, Alvinerie P, Butour J-L, Guillemot J-C, Ferrara P, Monserrat B, Mazargull H, Vassart G, Parmentier M, Costentin J (1995) Isolation and structure of the endogenous agonist of opioid receptor-like $\mathrm{ORL}_{1}$ receptor. Nature 377:532-535.

Muren JE, Lundquist CT, Nassel DR (1993) Quantitative determination of myotropic neuropeptides in the nervous system of the cockroach Leucophaea maderae-distribution and release of leucokinins. J Exp Biol 179:289-300.

Nachman RJ, Holman GM, Hayes TK, Beier RC (1993) Structureactivity relationships for inhibitory insect myosuppressins: contact with the stimulatory sulfakinins. Peptides 14:665-670.

Nassel D (1993) Insect myotropic peptides: differential distribution of locustakinin- and leucokinin-like immunoreactive neurons in the locust brain. Cell Tissue Res 274:27-40.

Pannabecker TL, Hayes TK, Beyenbach KW (1993) Regulation of epithelial shunt conductance by the peptide leucokinin. J Membr Biol 132:63-76.

Peralta EJ, Winslow JW, Peterson GL, Smith DH, Ashkenazi AJ, Ramachrandran J, Schimerlik MI, Capon DL (1987) Primary structure and biochemical properties of an M2 muscarinic receptor. Science 236:600-605.

Probst WC, Snyder LA, Schuster DI, Brosius J, Sealfon SC (1992) Sequence alignment of the $\mathrm{G}$ protein-coupled receptor superfamily. DNA Cell Biol 11:1-20.

Reinscheid RK, Nothacker H-P, Bourson A, Ardati A, Henningsen RA, Bunzow JR, Grandy DK, Langen H, Monsma FJ, Civelli O (1995) Orphanin FQ: a neuropeptide that activates an opioidlike $\mathrm{G}$ proteincoupled receptor. Science 270:792-794.

Roepstorff P, Fohlman J (1984) Proposal for a common nomenclature for sequence ions in mass spectra of peptides. Biomed Mass Spectrom 11:601-602.

Sambrook J, Fritsch EF, Maniatis T (1989) Molecular cloning: a laboratory manual, 2nd Ed. Cold Spring Harbor, NY: Cold Spring Harbor Laboratory.

Sanger F, Nicklen S, Coulson AR (1977) DNA sequencing with chainterminating inhibitors. Proc Natl Acad Sci USA 74:5463-5467.

Schoofs L, Holman GM, Proost P, van Damme J, Hayes TK, de Loof A (1992) Locustakinin, a novel myotropic peptide from Locusta migratoria, isolation, primary structure, and synthesis. Regul Pept 37:49-57.

Schmid A, Becherer C (1996) Leucokinin-like immunoreactive neurones in the central nervous system of the spider Cupiennius salei. Cell Tissue Res 284:143-152.

Smart D, Johnston CF, Shaw C, Halton DW, Buchanan KD (1993) Use of specific antisera for the localization and quantitation of leucokinin immunoreactivity in the nematode, Ascaris suum. Comp Biochem Physiol C 106:517-522.

Tensen CP, Cox KJA, Burke JF, van der Schors RC, Meyerhof W, Richter D, Planta RJ, Vreugdenhil E, van Heerikhuizen H (1994a) A novel successful strategy toward the identification of endogenous ligands for cloned "orphan neuropeptide receptors." Soc Neurosci Abstr 20:28.

Tensen CP, van Kesteren ER, Planta RJ, Cox KJA, Burke JF, van Heerikhuizen H, Vreugdenhil E (1994b) A G protein-coupled receptor with low density lipoprotein motifs suggests a role for lipoproteins in G-linked signal transduction. Proc Natl Acad Sci USA 91:4816-4820.

Veenstra JA (1994) Isolation and identification of three leucokinins from the mosquito Aedes aegypti. Biochem Biophys Res Commun 202:715-719.

Yokota Y, Sasai Y, Tanaka K, Fujiwara T, Tsuchida K, Shigemoto R, Kakizura A, Ohkubo H, Nakanishi S (1989) Molecular characterization of a functional cDNA for rat substance P receptor. J Biol Chem 264:17649-17652. 